Jurnal DISASTRI (Pendidikan Bahasa dan Sastra Indonesia)

Volume 3, Nomor 2, Agustus 2021| P-ISSN : 2716-4114 | E-ISSN: 2722-3329

\title{
PERSONALITY STRUCTURE IN THE NOVEL CLEANING CONSCIENCE BY ARIO MUHAMMAD (STUDY OF LITERATURE PSYCHOLOGY)
}

\author{
Afiva Rizky Pratiwi ${ }^{1}$, Alfian Setya Nugraha ${ }^{2}$ \\ ${ }^{1,2}$ Pendidikan Bahasa dan Sastra Indonesia, Fakultas Ilmu Pendidikan, Universitas Hasyim Asy’ari
}

Corresponding Author : ${ }^{1}$ Afivarizky2@gmail.com

\begin{abstract}
The research of the novel Membersihkan Nurani by Ario Muhammad can be used as a reference in understanding a person's personality and behavior. With the personality structure that occurs in the main character, it is presented in a very interesting discussion topic to study. This study aims to better understanding the personality structure experienced by the main character. The approach in this study uses the study of literary psychology. The data collection technique is done by means of semiotic analysis. This study uses analytical techniques by reading the next repeatedly by giving a sign it can be easily understood. The personality structure described in this discussion uses the psychoanalyst Sigmund Freud's analysis. The result showed that the main character in the novel was dominated by using the super ego personality. It can be stated that my character has the strongest dominance related ti personility and emotions.
\end{abstract}

Key Words: inner conflict, personality dynamics, semiotic

\section{STRUKTUR KEPRIBADIAN DALAM NOVEL MEMBERSIHKAN NURANI KARYA ARIO MUHAMMAD (KAJIAN PSIKOLOGI SASTRA)}

\begin{abstract}
Abstrak
Penelitian novel Membersihkan Nurani karya Ario Muhammad dapat dijadikan acuan dalam memahami kepribadian seseorang dan perilaku. Dengan adanya struktur kepribadian yang terjadi pada tokoh utama disajikan dalam sebuah topik pembahasan sangat menarik untuk diteliti. Penelitian ini bertujuan untuk lebih memahami struktur kepribadian yang dialami oleh tokoh utama. Pendekatan dalam penelitian ini menggunakan kajian psikologi sastra. Dengan teknik pengumpulan data dilakukan dengan cara analisis semiotik. Penelitian ini menggunakan Teknik analisis dengan cara membaca teks secara berulang-ulang dengan memberikan tanda untuk setiap makna yang memiliki arti luas. Penelitian ini bersifat deskriptif. Struktur kepribadian yang dijelaskan dalam pembahasan ini menggunakan analisis Psikoanalis Sigmund Freud. Hasil penelitian menunjukkan adanya tokoh utama dalam novel yang didominasi lebih menggunakan kepribadian super ego. Hal ini dapat dinyatakan tokoh aku memiliki dominasi paling kuat yang berkaitan dengan kepribadian dan emosi.
\end{abstract}

Kata kunci : konflik batin, dinamika kepribadian, semiotik.

\section{PENDAHULUAN}

Psikologi kepribadian merupakan suatu ilmu yang menyelidiki dan mempelajari tentang tingkah laku atau perilaku manusia. Dengan kata lain dalam pembahasan ini menampilkan suatu kepribadian manusia dengan objek penelitian dan faktor-faktor yang mempengaruhi tingkah laku manusia. Struktur kepribadian sendiri menitik beratkan pada pembahasan kondisi kejiwaan yang dialami tokoh utama dalam menyelesaikan masalah agar senantiasa bisa menjadi dirinya sendiri. Semua perjalanan yang di lalui tokoh utama dalam Novel Membersihkan Nurani ini meninggalkan banyak pesan yang diambil . Permasalahan dalam penelitian ini menimbulkan pro dan kotra antara Kepribadian Id dan Super ego yang belum menyatu dalam suatu tindakan. Tokoh 
utama menitik beratkan perilaku dan keyakinannya pada Super Ego bertugas penentu hal yang salah dan benar. Dengan keyakinan yang kuat tokoh aku lebih mengarah kepada hal yang positif untuk mencapai tujuan yang ingin ia capai.

Konflik pertentangan antara id dan super ego dalam dirinya. Sampai akhir dari menahan dan menetapkan tujuan utama dalam mencari ridha-Nya. Di setiap Penjelajahan dan perjalanan setiap amal perbuatan manusia akan dicatat oleh malaikat. Hingga saat nya tiba akan terbayar dengan pahala dan amalan yang akan senantiasa tetap terjalin dalam doa dan setiap perbuatan sampai perjalanan yang ditapaki. Cerita fiksi novel Membersihkan Nurani juga banyak memberikan wawasan luas akan budaya dan cerita islam pada saat pemerintahan sahabat -sahabat nabi. Penerapan hidup dengan kesederhanaan dan banyak bersyukur atas semua yang telah diberikan. Dengan dominasi adanya kepribadian dalam diri tokoh Utama. Peneliti memfokuskan kepada tokoh aku dengan menggunakan struktur kepribadian dengan analisis dari teori yang dikemukakan oleh Sigmund Freud. Adapun Struktur Kepribadian itu terdiri atas id, ego, super ego. Begitu pula yang ada dalam Novel Membersihkan Nurani banyak konflik yang terjadi di dalam cerita. Struktur kepribadian id yang ada di dalam novel diantaranya adalah diceritakan dalam sebuah perjalanan tokoh Aku mempunyai itikad untuk menjalankan ibadah sesuai ajaran agamanya dengan melaksanakan ibadah shalat. Dengan adanya id ini tokoh aku berinisiatif untuk shalat di jalan pejalan kaki lewat di sekitar area MRT. Dengan hal ini Ego pun melaksanakannya sesuai realita yang ada dengan mengambil wudhu di kamar mandi dan menunaikan shalat. Adanya sebuah keimanan yang kuat dan taat terhadap segala aturan yang sudah ditetapkan tokoh utama mempunyai kepribadian yang sangat baik dengan pertimbangan yang matang Super Ego dalam hal ini menuntun keniatan dalam diri tokoh aku menuju hal yang positif.

Pandangan dari pencetus adanya Psikoanalis dengan kajian Psikologi sastra
Sigmund Freud mengungkapkan bahwa adanya konflik semuanya berdasarkan dari tingkah laku dan saling berkaitan dengan adanya ketiga sistem kepribadian. Adapun beberapa faktor yang mempengaruhi adanya kepribadian dalam diri setiap manusia dapat dicontohkan adalah suatu faktor cerita di masa lalu yang masih terngiang dalam ingatan, faktor lingkungan pun juga sangat berperan penting dalam pengaruh psikis seseorang. Dengan adanya hal tersebut dapat disebutkan bahwa faktor tersebut memang bawaan dari lahir dalam diri setiap manusia.Penjelasannya Freud kembali memaparkan adanya tiga psikis kepribadian yang dimiliki oleh setiap manusia diantaranya kepribadian id yang bertugas sebagai penguasa tertinggi, manja, sewenang-wenang, harus dihormati dalam hal ini id memang sangat berpengaruh dalam pemuas kebutuhan.Kedua Ego dengan adanya psikis Ego yang diibaratkan sebagai penyelesaian segala pekerjaan yang berhubungan dengan kenyataan yang terjadi.

Adanya kepribadian ego tersebut sebagai pelaksana kemauan id untuk memuaskan segala keinginanya. Dengan adanya ego semua belum berjalan dengan semestinya Kepribadian terkahir ialah Super ego yang memiliki kehendak yang lebih besar dengan lintasannya Super ego berhak mengatur kemauan dan keinginan id dalam memuaskan. Super ego dikatakan mempunyai norma dan aturan dalam setiap perlakuan yang akan dijalani dan pemikiran Super Ego sebagai penentu dalam tindakan. Beberapa penjelasan terkait Psikis kepribadian Super Ego yang di ibaratkan sebagai pendeta yang selalu penuh dengan pertimbangan terhadap nilai-nilai baik dan buruk harus mengingatkan id. Menjalankan tugas untuk pemuas kebutuhan sehingga dengan mudah mencari jalan terbaik akan selalu ada kegundahan dalam diri seseorang. Super ego dan Id lah yang selalu bertentangan sehingga sering kali pemikiran yang bimbang akan suatu hal bisa diakibatkan karena ada keinginan yang id peroleh sehingga Super ego menimbangkan dengan hal yang matang. Apabila tidak sejalan dengan pemikiran akan mengakibatkan sebuah kebimbangan 
dalam menentukan suatu hal perbuatan. Setiap peristiwa yang dialami dalam setiap manusia pernah mengalami suatu gejala tersebut dengan adanya pemikiran yang matang dapat juga mengakibatkan permasalahan yang melanggar norma dan aturan yang sudah dijelaskan dalam pengertian Super ego. Dengan ini adanya Super ego sangat di butuhkan dalam penengah atau pemecah suatu masalah.

Masalah yang diangkat dalam penelitian ini adalah adanya struktur kepribadian yang dialami tokoh utama dalam novel Membersihkan Nurani ditinjau dari struktur kepribadian Sigmund Freud yang meliputi adanya Id, Ego,dan Super ego. Secara umum tujuan penelitian ini mendeskripsikan struktur kepribadian tokoh dalam novel Membersihkan Nurani menggunakan Psikologi sastra.

Ada beberapa fenomena yang sering tidak disadari oleh setiap manusia dalam memutuskan suatu hal dapat dicontohkan pengendalian dalam Super Ego ialah mampu membawa sang id dalam hal yang positif tidak dengan hal yang negatif. Adanya kemenangan Super ego ialah memenangkan penguasaan terhadap psikis id dan menjalankan ego sesuai realita. Fenomena sering terjadi dimasyarakat adanya kriminalitas yang semakin tinggi dikarenakan banyak pemutusan hubungan kerja di tiap perusahaan. Hal ini menjadikan sebagian manusia memilih untuk mencari kembali pekerjaan agar bisa memenuhi kebutuhan keluarga. Dengan dunia yang keras akan banyaknya himpitan ekonomi kepala keluarga apabila dimunculkan kesadarannya dengan memenangkan super egonya meredahkan id keiginannya dan menjalankan sesuai aturan yang ditentukan oleh super ego. Dengan arti sebuah kehidupan adalah pilihan dengan pemilihan yang matang dan mempertimbangkan dampak akan terjadi selanjutnya. Dalam hal ini adapun banyak diantara mereka yang memilih untuk mencuri dan melakukan kejahatan lainnya demi pemenuhan keinginannya, damapak yang akan terjadi pun sangat fatal dan belum bisa dipastikan akan dimenangkan akan Psikis Superego nya melainkan dimenangkan oleh Psikis Id dalam dirinya. Semua memang merupakan hal yang sebuah pilihan dan penentu yang terbaik dan tak baik buat diri kita.

Menurut Pemaparan Freud terkait, kekuatan id ini mengulas akan tujuan sebenarnya suatu kehidupan hakiki oleh individu. Hal ini dapat tercakup dalam sebuah pemenuhan kepuasan. Kepribadian Id tidak mampu mewujud nyatakan tujuan mempertahankan kehidupan atau melindungi kondisi dari bahaya. Tugas ego dalam hal Ini, mencari cara memenuhi kebutuhan dan kepuasan. Struktur kepribadian yang dialami Super ego mengendalikan keinginan-keinginan tersebut.Kajian kepribadian dapat diartikan sebagai kajian mengenai bagaimana seseorang menjadi dirinya sendiri, setiap manusia memiliki banyak pengalaman sendiri-sendiri yang belum tentu dimiliki oleh orang lain. Oleh karena itu, pengalaman adalah penentu lingkungan dan sangat berpengaruh dalam tumbuh kembang anak untuk mencari jati diri ia sesungguhnya.

\section{Metode Penelitian}

Penelitian ini menggunakan pendekatan penelitian deskriptif kualitatif, yaitu data penelitian berupa rangakaian kata, frasa, kalimat serta paragraf untuk mendeskripsikan dan menemukan makna yang utuh dari objek. Menurut pandangan Siswantoro beranggapan bahwa dengan adanya sebuah penelitian sastra begitupun dengan penelitian disiplin lain, bersandar dengan metode yang sistematis. Penelitian ini bersifat deskriptif , karena itu metodenya juga digolongkan dalam metode deskriptif. Peneliti menggunakan analisis tersebut bersifat menarasikan hasil kajian.

Menurut pendapat dari Saryono sebuah penelitian kualitatif diakatakan sebuah yang biasa yang digunakan untuk menyelidiki, menemukan, menggambarkan,dan menjelaskan kualitas dan keistimewaan dari pengaruh sosial yang tidak dapat dijelaskan, diukur, maupun digambarkan melalui pendekatan kuantitatif. Peneliti menggunakan teknik reduksi data yang dimaksud dalam penelitian ini adalah menyeleksi kata-kata atau dialog dalam novel Membersihkan 
Nurani karya Ario Muhammad. Proses mengumpulkan data dalam penelitian ini dengan menggunakan tiga cara yaitu membaca, mencatat, dan mengode. Bentuk penelitian ini adalah deskriptif kualitatif dengan metode analsis data.

Teknik dalam pengumpulan data merupakan sebuah langkah awal yang dilakukan sebelum melakukan sebuah penelitian. Teknik pengumpulan data dalam penelitian ini menggunakan sebuah teknik pustaka atau dokumen. Teknik analisis data dalam penelitian ini menggunakan konsep semiotika yang merupakan salah satu teknikuntuk mengetahui dan memahami karya sastraserta bisa diartikan bahwa semiotik dapat berupa sebuah pengalaman, pikiran, perasaan, dan lain-lain.

Teknik analisis yang digunakan dengan cara membaca teks secara berulangulang dengan memberikan tanda untuk setiap makna yang memiliki arti luas, sehingga dengan adanya tanda tersebut dapat mudah dipahami.Teknik semiotika, yang memiliki tahapan, yaitu tahapan pertama membaca dengan cermat dengan berulang-ulang novel Membersihkan Nurani Karya Ario Muhammad penelitian ini dengan mengelempokkan data yang masuk ke dalam tokoh.

Selanjutnya dengan cara menandai setiap kata, frasa, kalimat atau paragraf yang ada di dalam novel Membersihkan Nurani Karya Ario Muhammad. Dengan tahapan terakhir ini peneliti memberikan kode pada data yang ditemukan.Tujuan memberikan kode untuk mempermudah dalam peneliti untuk mengidentifikasi data yang akan diteliti.

\section{PEMBAHASAN}

\section{Struktur Kepribadian}

Dalam struktur kepribadian konflik
batin yang terjadi dalam novel
Membersihkan Nurani karya Ario
Muhammad. Dalam rangkaian cerita yang
ada dalam sebuah karya sastra Novel
karangan Ario Muhammad ini ada banyak
semacam Psikologi kepribadian tokoh
terhadap konflik batin yang terjadi. Ada
beberapa konflik yang terjadi dan

mempengaruhi jiwa dan fikiran tokoh utama konflik pertama ialahsebuah rasa kerinduan akan salah seorang perawat di Halmahera dengan berbagai konflik dirancang agar rasa rindu tidak berujung dengan sangat dalam. Berikut beberapa contoh data dialog atau kata- kata dalam novel Membersihkan Nurani Karya Ario Muhammad.

“...........Apalagi jika renunganku mulai mengembara ke Pulau Halmahera. Keindahan teluknya,lautnya,hutan hijaunya,hewan-hewan liarnya, semua adalah rangkuman cerita tentang permata surga yang Allah titipkan bagi bumi pertiwiku. Seperti biasa, ketika bayanganku bercermin pada catatan-catatan waktu yang mengejar di masa lalu, maka raut wajah mereka-mereka yang mencintaiku akan kembali hadir. Teringat seorang perawat di Pulau Halmahera yang berjuang di tengah gulita, kadang suaranya dalam telepon menghapus semua kerinduan yang mengendap-endap............'(MN02.1.1)

Data MN02.1.1 dapat dikatakan dengan . Struktur Kepribadian dalam dirinya sangatlah kuat dikarenakan Super Ego yang ada dalam dirinya memilih sebuah keputusan dengan mengalah dan memutuskan untuk berfikir kedepan dengan realistis. Id dalam dirinya ingin mengingat sesuatu yang ia rindukan dengan pengaruh Super ego yang kuat akhirnya ego pun melakukan dengan pengaruh Super ego. Dalam data ini sangat kuat pengaruh Super Ego dikarenakan hal yang sangat berharga hanyalah masa depan yang cerah dengan menggapai impian dan tidak melihat masa lalu.

Adapun struktur kepribadian kedua. Menjelaskan bahwa ada sebuah keputusasaan terkait kehidupan. Penyesalan akan bertemu terkahir bukan saat ini. Dengan berbagai hal yang ia lakukan semua akan kembali Kepada-Nya. Segala permasalahan memang bis diselesaikan dengan mudah bukan dengan rasa menyerah akan menjadi dari akhir kehidupan. Semua ada masanya dan ada waktunya untuk kita menenangkan diri dari belenggu permasalahan diluar. Dalam novel yang tersaji adalah rasa perasaan bersalah yangmendalam atas kesalahan yang ia 


\section{Jurnal DISASTRI (Pendidikan Bahasa dan Sastra Indonesia) \\ Volume 3, Nomor 2, Agustus 2021| P-ISSN : 2716-4114 | E-ISSN: 2722-3329}

lakukan akan tetapi perlawanan dari tokoh aku muncul dengan ambisi menuntaskan segala persoalan. Penyelesaiannya hanya dengan ketenangan baik jiwa dan berserah diri padanya. Merupakan sebuah solusi terindah. Ada data yang mengatakan adanya suatu kemalasan yang menjerat dalm diri tokoh Utama dengan belenggu penyelesaian tugas. Rasa Bersyukur dan berharap terus tetap merasakan jiwanya seperti ini. Membuat dampak positif baik untuk tokoh utama maupun untuk pembaca sebagai pembelajaran agar senantiasa tunduk patuh taat akan ajaran dan tuntunannya.

“ ........... Dua novel, 1 buku "ringan", dan 3 buku "berat". Tiba-tiba saja mulai kurenungkan. Tentang malam ini, hari lalu, hari esok, empat tahun lagi, kelulusan S2, rencana S3, dan semua targetan hidup yang kurancang. Aku tergelitik sendiri memandang hati dan jiwaku. Ternyata tak punya apa-apa untuk sekedar "mengangkat" semua amanah dan beban yang ada di depanku. Ah, aku tak ingin melanjutkan tentang amanah dan beban. Mempertanggung jawabkan apa yang telah diberikan Allah kepadaku saja sudah tak mampu kuuraikan................ (MN.02.1.2)

Berdasarkan data (MN.02.1.2)

struktur kepribadian yang terjadi terlihat suatu kemalasan yang mulai menguasai diri tokoh utama dengan berbagai tindakan dan kepekaan diri dalam menangani sitausi tersebut. Terlihat banyak pengaruh id dengan keinginan menuntaskan sebuah tujuan. Dengan adanya pengaruh Super ego dalam penanganannya lebih mengedepankan rasa syukur dan rasa sadar bahwa manusia lebih sering dengan kebiasaan kemalasan tanpa ia sadari. Id sudah dikontrol oleh pengaruhnya Sehingga Super ego yang hanya bisa pasrah dan mengikuti alur yang diputuskan oleh id. Ego dalam hal ini mengikuti alurnya sehingga memutuskan untuk yasudahalah ini sudah keputusannya. Dengan hal seperti ini dijelaskan lebih jelas lagi bahwa antusias dalam menyelesaikan tesis semakin berkurang dengan disebabkan beberapa kejenuhan yang terjadi dalam diri tokoh Aku.

Banyak fenomena suatu peristiwa menitik beratkan pada kejenuhan dan sehingga timbullah stres yang berlebihan dikarenakan tak mampu otak dan saraf menyelarasakan dengan perilaku. Sehingga efek samping dari ini adalah linglung dan tidak faham akan menyelesaikan seperti apa. Setiap individu memang ditakdirkan berbeda dalam menerima situasi dan keadaan yang menekannya, ada banyak hal apabila ditanggapi dengan emosi positif akan menunjukkan ke optimisan dan keyakinan yang kuat akan penyelesaian misi dalam diri tokoh aku. Apabila yang terjadi sebaliknya Emosi negatif yang terjadi dalam diri tokoh aku malah sebaliknya. Stres dengan sitausi yang menghimpit, gampang marah, dan resah. Perasaan yang tidak tenang dapat juga merusak saraf dengan banyaknya kecemasan tanpa ada tindakan.

Dengan putus asa dan mengakhiri hidup bukanlah hal yang baik dan tak patut untuk di jadikan prinsip, keinginan mati dalam ajaran agama islam sangatlah tercela dan tidak akan diampuni dosa-dosa bagi orang yang mati dikarenakan mencelakakan dirinya sendiri. Tokoh aku mengambil keputusan sangat benar dengan keputusan yang tepat dalam memutuskan suatu pilihan hidupnya. Dalam hal pertimbangan mental dari Super ego sangat tepat pemilihan keputusan dari super ego dengan pengingat akan ajaran dan aturan yang sudah ditetapkan dalam ajaran agama masing-masing. Id dan super ego memang selalu bertentangan, akan tetapi dalam diri tokoh tersebut dapat mengontrol sesuai dengan alur yang akan dipergunakan untuk hal yang positif.

Banyak hal yang terjadi terkait konflik batin yang tengah ia alami dengan kesadaran yang penuh dan realita yang jelas. Dalam hal ini bisa kita buat pelajaran untuk setiap manusia dalam mengambil keputusan sebaiknya benar-benar dimatangkan dan jangan terlalu mengandalkan id yang tak tentu benar dan dalam hal positif. Semua pengalaman kejadian bisa di jadikan patokan dalam mempelajari hal yang positif dan berguna bagi masa depan maupun kelangsungan kehidupan.

Analisis ketiga, mulailah timbul perasaan malas dan tak mau bertindak 


\section{Jurnal DISASTRI (Pendidikan Bahasa dan Sastra Indonesia) \\ Volume 3, Nomor 2, Agustus 2021| P-ISSN : 2716-4114 | E-ISSN: 2722-3329}

dalam kegiatan yang membuat sebuah konflik batin dalam diri tokoh aku. Kutipan ini akan menunjukkan ketidak berdayaan yang dialami tokoh aku. Sifat kemalasan memang sudah tertanam dalam diri manusia dikarenakan oleh nafsu manusia. Pengendalian kemalasan tergntung dalam setiap pribadi manusia itu sendiri.

“...............Mungkin karena kita masih tetap di sini, di balik selimut yang hangat serta bantal kepala yang empuk untuk ditiduri, kita masih pulas di sana, dalam buaian mimpi yang terus menjejali, juga kelelahan-kelelahan yang sering terjadi karena memang kita lalai. Kita memang masih disini ditumpukan kemalasan sedang matahari sudah mulai terbit dari timur, sedang embun pagi mulai membasahi bumi yang dingin.. “(MD.02.1.3).

Berdasarkan kutipan data (MD.02.1.3) di atas terlihat banyaknya faktor psikologi yang sering menjadikan kita malas dalam melakukan suatu hal. Dengan adanya hal tersebut kepribadian Id lah yang mengontrol segalanya Super Ego yang bertugas menjadi lintasannya mencoba mengatur dengan kekuatannya agar penyelesaian akan berjalan sesuai alur. Ryff mengatakan sebuah perasaan yang tertanam dalam setiap individu memiliki aspek positif dan negatif. Apabila ia memilih aspek positif dalam penyelesaiannya akan memberikan sebuah tantangan dari tujuan yang berpengaruh pada kesejahteraan psikologis. Sehingga apabila tidak punya semangat untuk menjalankan dan tipisnya harapan untuk mencapai suatu kesuksesan dapat menimbulkan suatu aspek negatif dalam diri seseorang. Oleh karena itu tujuan hidup yang berkualitas dapat berpengaruh pada proses pencapaian sehingga dengan halnya jangkauan seperti itu dapat meningklatkan kesejahteraan psikologis pada individu(Shelldon \&Elliet,2001).

Dalam data keempat analisis tokoh utama dengan yang dikisahkan oleh tokoh aku tentang salah seorang dari tiga pemuda beriman yang melakukan sebuah perjalanan jauh, hingga suatu ketika memutuskan untuk menginap di dalam gua. Kejadian di dalam gua terjadi dengan kasus Jalan menuju pintu keluar gua telah tertutup oleh batu besar yang menutupi gua tersebut sehingga ketiga pemuda tersebut tidak bisa keluar dari dalam gua. Dalam keadaan yang membuat situasi genting dan tidak tau ingin minta pertolong oleh siapa tiada orang dan disini hanya bertiga meminta pertolongan pada Sang pencipta. merupakan hal yang selalu kita lakukan. Dalam penjelasan seperti ini lah sebuah proses kisah ini bermulai. Adanya nafsu, cinta, dan senantiasa takut kepoada Allah SWT. Salah seorang dari pemuda ini pun mengatakan bahwa ia berterus terang dengan kesalahan yang telah ia lakukan sehingga dalam penjelasannya seperti data berikut banyak hal yang diluar kendali manusia bisa terjadi.

$$
\text { “ ..............Ya Allah....." ujarnya }
$$

lirih.aku memiliki seorang saudara sepupu yang sangat aku cintai. Laku dan parasnya yang cantik membuatku. Jatuh cinta selayaknya ketertarikan seorang laki-laki kepada perempuan" lanjutnya. aku begitu tergoda dengannya hingga nafsu menguasai seluruh jiwaku. Kurayu dia agar bercinta denganku, namun dia menolaknya," suara parau mengingat dosa yang mengimpit dada............ (MD.02.1.4).

Dari data di atas (MD.02.1.4). terdapat suatu kejadian sebuah perlawanan antara nafsu dan cinta serta dalam mencari keridaan Allah Sang Maha Esa. Dengan adanya kepribadian Id yang menguasai banyak perselisihan antara Super ego dan id sehingga dengan suatu hal yang melanggar larangan agama dan menyalahi aturan Super ego bertindak dengan kebenaran yang terjadi. Sampai akhirnya Super ego nya lah yang memutuskan jalan yang terbaik dalam dirinya. Dengan cara menghentikan dengan cara di ingatkan oleh saudaranya akan aturan dan norma yang sudah tercatat dalam kitab suci. Karena dengan perbuatan ini sangat dibenci oleh Allah. Mencari jalan yang tak merugikan satu sama lain tetap dalam lindungan-Nya. Kisah tersebut mengaitkan banyak problema yang sering terjadi dalam kehidupan.

Kelima menjelaskan lebih detail terkait Struktur kepribadian konflik batin yang terjadi dalam novel. Banyak sekali keikhlasan dalam hatinya tentang sebuah 
persoalan dalam menyelesaikannya. Tetap percaya diri dan tidak berambisi untuk menjadi yang sempurna. Dalam segala apapun yang ia lakukan tetap lah mengingat akan hadirnya Allah. Dalam isi data sebagai berikut yang menjelaskan tentang adanya yang sangat santun dan taat dalam ajaran . ...Bulan bersinar indah menghiasi langit, birunya yang jernih memantulkan beribu keindahan malam di musim panas. Kukayuh sepedaku sepulang dari masjid besar setelah buka puasa. Perlahan kusapu hati yang mulai sedikit lena dengan dunia. Bahkan sedikit rupanya, namun terlalu sering jiwa terbuai dengan pesona dunia. Kemudian, seperti suarasuara penghambaan yang mulai berteriak pada paket malam, disitulah cerita tentang tobat mulai dilantunkan.........."MD.02.1.5)

$$
\text { Dalam data (MD.02.1.5) dapat }
$$

dijelaskan dengan adanya Struktur Kepribadian masing-masing penyelesaian sangat berebeda. Dalam kasus tersebut dijelaskan akan adanya penguasaan diri dalam menuntaskan pikiran dari kejenuhan terhadap penyelesaian tesis yang sedang ia kerjakan. Dalam proses pembahasan penyelesaian tak lupa senantiasa terus berserah diri kepada-Nya. Hal yang terus menerus ia lakukan agar dengan penyelesaian berjalan sempurna. TanpaNya kita memang bukan apa-apa. Banyak tragedi yang dijelaskan dalam naskah cerita bahwa dalam kefanaan ini kita hidup, dalam belenggu dunia yang tak nyata. Inilah kehidupan dengan berbagai peristiwa yang terjadi kita bisa belajar untuk menghargai segala proses yang sudah ada. Teruslah bersyukur dan senantiasa berbenah . Id yang berperan sebagai penyemangat dalam hal baik sebagai ego melakukan sesuai kehendak id dengan hal yang nyata sehingga pengambilan keputusan Superego bisa sesuai dengan apa yang dikehendaki dengan berbagai macam rintangan perlawanan. Penyemangat dalam diri memberi arti positif untuk menyelesaikan suatu kondisi yang terjadi dalam tokoh aku. Konflik tersebut menjelaskan bahwa sebenarnya ia lelah dengan semuanya tapi dengan cara apapun ia harus tetap selesai dengan caranya. Kesabaran dan senantiasa bersyukur merupakan hal yang ampuh dalam bertahan mencari jati diri.

Analisis ke-enam lebih menjelaskan tentang adanya keresahan dalam diri tokoh utama dalam novel Membersihkan Nurani karya Ario Muhammad dengan berbagai cara dan berbagai rintangan yang dilakukan hanya dengan teman secarik kertas dan mengungkapkan keluhan dan kesah yang tak kunjung tuntas tokoh utama mencoba berbincang terkait masalah yang saat ini ia hadapi. Dengan berbagai peristiwa tokoh aku menjelaskan terkait adanya persoalan yang kian lama mempersulit dia dalam penyelesaian tesis.

Banyak hal yang tidak ia sadari dalam penyelesaian tesis. Adapun data yang diperoleh dari novel Membersihkan Nurani karya Ario Muhammad yang menitik beratkan dengan sebuah argumen keluhan. Data yang diperoleh dari penjelasan data diatas sebagai berikut.

“ ........... Tapi ia merupakan catatan permulaan untuk mengambil entakanentakan dahsyat untuk menaklukan dunia. Tentu, perjuangan ini bukan hanya dilakukan olehku, karena kehadiran Anda, dan semua yang mau berkomitmen teguh dijalan-Nya adalah gabungan kukuh untuk meretas kembali kekuatan generasigenerasi syahadatain yang pernah ada. Maka pejamkanlah mata kita, resapi kehadiran Allah dalam hati kita, kemudian, serukanlah sekuatnya di dalam jiwa kita, bahwa " komitmen adalah totalitas sebuah perjuangan".(MD.02.1.7)

Penelitian data ke tujuh memaparkan tentang arti sebuah keluhan yang dialami oleh setiap manusia. Dengan struktur konflik batin yang terjadi antara keluhan dan tindakan tokoh utama. Menyelaraskan berbagai peristiwa yang terjadi sehingga dalam data berikut akan menyeimbangkan persoalan masalah hingga tahap penyelesaian. Berikut ini data yang akan dijelaskan dalam konflik yang terjadi dalam novel. Pengaruh dalam komitmen dan percaya diri sangat tinggi menjelaskan bahwa pengaruh kepribadian Id memang sangat tinggi karena sebuah keinginan dan sebuah motivasi yang dilakukannya. Kepribadian tokoh aku 


\section{Jurnal DISASTRI (Pendidikan Bahasa dan Sastra Indonesia) \\ Volume 3, Nomor 2, Agustus 2021| P-ISSN : 2716-4114 | E-ISSN: 2722-3329}

memang dikatakan sangat tangguh dan sangat kuat dalam berbagai rintangan dan hambatan akan tetapi emosi yang ditimbulkan naik turun. Akan tetapi adanya emosi yang ia rasakan tersebut menimbulkan berbagai macam konflik dalam diri. Adanya super ego yang selalu membawa Id ke dalam pengaruh yang lebih baik lagi. Dapat dikatakan kepribadian tokoh utama dalam novel Membersihkan Nurani tersebut dikatakan normal, dengan sewajarnya yang dilakukan oleh kebanyakan orang".

“ ...........Rabb, senja ini ku kirimkan lagi seuntai doa panjang untuk-Mu. Sekedar melepas lelah yang mulai bergelayut, menghapus jejak-jejak penantian dengan janji yang selalu terpatri di dalam diri, bahwa dari-Mu, selalu akan indah. .."Rabb, senja ini kuingin sekedar menghentikan kerjaku yang mulai terasa semrawut. Memanjakan hatiku dengan mengingat-Mu. Menenangkan penatku dengan bercerita panjang pada-Mu. Mengungkapkan semuanya

Mengungkapkan resahku tentang waktuwaktu yang akan datang, mengungkapkan harapku atas apa-apa yang berjalan dalam pekan-pekan terakhir ini, mengungkapkan keinginan agar selelu dalam takwa kepada$\mathrm{Mu}, . . . . . . . "(M D .02 .1 .8)$

Dengan secarik kertas dan mengungkapkan isi hati yang terdalam. Tokoh aku memang bukan orang yang mudah untuk menceritakan segala sesuatu kepada orang lain, melainkan keluhannya hanya ia kasihkan kepada Sang Pencipta. Rasa kasih sayang dan selalu ingin berada dalam lindungan-Nya. Yang diutarakan dalam perjalanannya, begitu banyak ambisi yang membara untuk melewati segalanya. Tanpa ada kuasa-Nya tak akan bisa bertahan sampai disini. Pengendalian id dalam cerita tersebut dikuasai dalam emosi sementara dengan keluhannya akan mengurangi rasa penat yang ada dalam diri toko Aku.

Analisis data selanjutnya data penelitian ke delapan dalam novel Membersihkan Nurani karya Ario Muhammad . Dalam gambaran kesusahan dan berbagai macam rintangan untuk penuntasan studi S-2 di Taipe tokoh utama menitik bertkan pada gagasan id, ego, super ego. Berbagai macam cara ia coba dengan mengontrol diri untuk selalu tetap waspada menuju jalannya. Pertentangan antara id, dan super ego tokoh utama dapat mengendalikan dengan sempurna. Adapun data yang akan dipaparkan terkait perjalanan yang begitu rumit hingga sampai pada tahap seutuhnya hidup. Sebuah kebebasan dalam hal yang sesungguhnya ia inginkan. Data tersebut dijelaskan sebagai berikut.

“ ...............Di setiap perjalanan, selalu ada misteri yang terungkap perlahan. Seperti semesta yang bertasbih di pantai selatan taiwan. Dengan ombak-ombaknya yang besar, gemuruh itu membawa pesan tentang kekuatan mahabesar penciptanya. Lalu, gelombang itu menghilang bersama dinding-dinding batu karang yang terjal, mengirimkan suara menggetarkan bagi manusia hingga mereka merasa bahwa Allah selalu di sana, di mana pun berada. Di setiap perjalanan, selalu ada cerita baru yang menguap tiba-tiba.

Dalam pembahasan data di atas dapat dikaitkan dengan akhir cerita dalam semua persoalan. Tokoh utama menyelesaikan semuanya dengan bahagia tanpa ada masalah dan persoalan yang menjadi masalah besar. dalam diri tokoh utama menitik bertkan persoalan yang beradu dalam jiwa dengan caranya hingga pada saatnya kebebasan pun telah datang dalam hidupnya.

Belenggu yang mengahantui semakin lama semakin pudar. Tanpa berfikir panjang asumsi untuk Super ego hingga berganti waktu semakin lama semakin indah. Dengan pemaparan tokoh utama tersebut menjelaskan akan kerasnya suatu proses kehidpuan. Dengan taat dan bersabar untuk mencapai tujuan. Tokoh utama memberikan asumsi pandangan yang positif. Sehingga pembaca juga dapat mencontoh akan perilaku dan tindakan yang dialami oleh tokoh utama dalam menyelesaikan masalah . Religuis dalam karakter tokoh aku sangat mengarah pada rasa bersyukur,kepercayaan, dan keimanan yang kuat, ketaatan dalam beragama 
menjadi insan yang taat akan segala karunia yang Allah kasih kepada kita.

Data selanjutnya dijelaskan dengan rasa keimanan dan keyakinan yang penuh dalam diri tokoh utama mengungkap bahwa halnya. Perasaan sayang cinta kasih akan perlindungannya, dan segala apa yang ia perbuat merupakan sebuah yang Tuhan kasih terhadap hambanya yang senantiasa bersyukur atas nikmat yang telah diberikan kepadanya. Rasa cinta tokoh utama memang sangat kuat dalam melakukan pengendalian diri tokoh aku merupakan pribadi yang baik dan karakter yang baik. Dengan adanya hal tersebut dinarasikan tokoh aku sangatlah taat dalam segala aturan dan ajaran yang sudah diterapkan dalam tradisi setiap agama. Adapun data yang dijelaskan sekilas dalam pembahasannya sebagai berikut.

“ ..................hingga pada satu titik, aku mengerti, aku yang telah bersumpah mempercayai Allah sepanjang hayat ini, masih malas berkerja dibanding para penghamba materi di pusat kota Hongkong. Aku yang meyakini Muhammad bin Abdullah adalah Rasul Allah............"

Pengendalian id dan ego yang dibantu dengan super ego membawanya ketahap menuju masa depan yang ia inginkan selama ini. Perjalanan panjang pun kini telah usai. Tapi kehidupan tokoh Aku dalam novel Membersihkan Nurani karya Ario Muhmmad masih terus berjalan dengan argumen yang ia buat untuk kehidupannya kedepan. Menghadapi dengan sabar, tawakal, bersyukur. Suatu hidayah dan karunia yang telah Allah beri kepada hambanya, yang senantiasa menyayangi dan mengagungkannya-Nya. Manusia memiliki ketangguhan untuk menghadapi kesulitan dan mengembangkan suatu pemaknaan positif dalam kehidupan.

Penulis menggaris bawahi terkait novel Membersihkan Nurani karya Ario Muhammad. Tidak ada seorang pun yang bisa bertahan hidup tanpa bantuan dari sang Maha Pencipta. Banyak keresahan, keputusasaan, ketidak pedulian, dan kemalasan yang ada dalam diri manusia. Semua dalam diri manusia dikontrol oleh Super Ego. Dikatakan engontrol semua sesuai lintasannya tergantung dengan keputusan yang akan dipilih. Kehidupan tak selamanya berjalan mulus banyak segala macam rintangan yang diperoleh dari sebuah pengalaman yang didapat. Dalam kenyataannya semua tergantung diri manusia sendiri mencoba belajar dari kesalahan atau lebih memilih meninggalkan masalah. Pengalaman yang disaring dan dijadikan argumen yang baik kemungkinan hasil yang di dapat sesuai dengan tujuan utama yang ia inginkan.

\section{SIMPULAN}

Penelitian ini berupaya menampilkan tentang tokoh Aku dengan menjelaskan lebih detail cerita dan beberapa konflik yang dihadirkan dalam novel Membersihkan Nurani karya Ario Muhammad. Berdasarkan hasil penelitian terkait Struktur Kepribadian dalam novel Membersihkan Nurani karya Ario Muhammad, dapat dikatakan lebih mengkaji kajian Psikologi sastra dengan mengambil beberapa aspek mulai dari id, ego, dan super ego. Dikatakan id apabila memiliki berbagai keinginan yang belum terpuaskan dan ego adalah suatu hal yang mengikuti id dengan bertindak. Tindakannya tersebut mengacu pada Super Ego menyeteujui apa tidak,

Super Ego merupakan sebuah pendeta dengan berbagai macam pertimbangan. Id dalam tokoh utama dikatakan membutuhkan sesuatu hal yang menurut dia menarik agar penelitian dia berjalan dengan sempurna, dengan karakter yang mudah putusasa, malas, dan belum bisa menyesuaikan dengan kondisi yang ada. Ego yang diamati tokoh utama adalah perlakuan yang positif dan tindakan yang melanggar aturan senantiasa tidak ia pedulikan. Dalam penelitian ini Super Ego lebih dominan dikarenakan banyak pengaruh yang terjadi di dalam sebuah peristiwa yang ada. Manusia senantiasa bersyukur dan meminta Ridha Illahi agar jalan kehidupan begitu mudah ia gapai dengan banyak tujuan. Tiada orang yang sukses tanpa berkerja. Semua perlu dengan adanya ikhtiar yang kuat untuk berserah diri kepada-Nya. Kunci kesuksesan adalah semangat, beruapaya, dan mendekati sang Pencipta. 


\section{DAFTAR PUSTAKA}

Nurgiantoro,B .2012. Teori pengkajian fiksi. Yogyakarta: Gadjah Mada University Press.

Semi Atar.2012. Metode Penelitian Sastra. Bandung: $\mathrm{CV}$ angkasa.

Wellek \& Werren. 2014. Teori Kesusastraan. Jakarta: Gramedia Pustaka Utama.

Muhammad Ario.2020. Membersihkan Nurani. Jakarta :NEA Publishing.

Siswantoro.2016. Metode Penelitian Sastra Analisis Struktur Puisi. Yogyakarta:Pustaka Pelajar.

Ratna, Nyoman Kutha. 2015. Teori, Metode, dan Teknik Penelitian Sastra. Yogyakarta: Pustaka Pelajar

Endraswara, Suwardi. 2013. Metode Penelitian Sastra. Yogyakarta: PT Gelora Pratama

Rosyid Alfa.2017.Kepribadian Tokoh Fahmi dalam novel Api Tauhid Karya Habiburahman El Shirazy (Kajian Psikoanalis Sigmund Freud ). Malang : Universitas Kanjuruhan Malang. https://www.researchgate.net/publ ication/338375887pada bulan july 2017.

Suprapto. 2018. Novel Jalan Tak Ada Ujung karya Muchtar Lubis. Ponorogo : STIKIP PGRI. Volume 5, No 1 Oktober 2018(http://www.jurnalnasional .ump.ac.id/index.php/METAFOR A/article/view/5028 diakses pada 6 Februari 2021.

Yulianti.2011. Analisis Karakter tokoh utama dalam Novel Dian yang tak kunjung Padam Karya S.Takdir Alisjabana ( Sebuah Pendekatan Psikologi Sigmund Freud). Skripsi tidak diterbitkan Makasar : Universitas Negri Makasar. 